\title{
Analysis of the representations of the concept of number proposed by a group of pre-service Primary Education teachers in Costa Rica
}

\author{
Miguel Picado-Alfaro iD a \\ ${ }^{\text {a } U n i v e r s i d a d ~ N a c i o n a l, ~ F a c u l t a d ~ d e ~ C i e n c i a s ~ E x a c t a s ~ y ~ N a t u r a l e s, ~ E s c u e l a ~ d e ~ M a t e m a ́ t i c a, ~ H e r e d i a, ~ C o s t a ~}$ \\ Rica
}

Received for publication on 28 Set. 2020. Accepted after review on 15 Dec. 2020

Designated editor: Claudia Lisete Oliveira Groenwald

\begin{abstract}
Background: Educational reforms in mathematics imply a series of changes in teacher training. Some of these modifications accentuate the inclusion of new content, the development of mathematical abilities, skills, or competencies, and the implementation of different teaching and assessment strategies, and the use of technology. Primary and secondary education teachers must be able to respond adequately to these curricular standards. In Costa Rica, mathematics education has undergone changes to promote various cognitive processes in students, such as those of number representation. Objectives: The article highlights the diversity of representation systems assigned to the concept of number, proposed by a group of Costa Rican preservice Primary Education teachers, as a promoting agent for the development of processes of representation in students. Design: Theoretically, the research is structured around proposals for the analysis of the meanings of mathematical concepts as associated to teacher training. It is a descriptive study based on an intrinsic case study. Data collection and analysis: The information was collected through a questionnaire. Information analysis highlights the existence of different forms of representation and the justification arguments that the participants apply for their selection; content analysis was used as the analytical technique. Setting and participants: The study was carried out with 23 preservice Primary Education teachers. Results: The results reveal a trend in the use of representation systems of the same form to present the concept of number, particularly iconic and symbolic-numeric representations. Conclusions: A connection is observed between the proposed representations and situations and contexts that seem to be familiar to Primary Education students; this relation deserves further exploration.
\end{abstract}

Keywords: Primary Education; Pre-service teachers; Number; Systems of representation.

Autor correspondiente: Miguel Picado Alfaro. Email: miguel.picado.alfaro@una.cr 


\section{Análisis de las representaciones del concepto de número que propone un grupo de docentes de educación primaria en formación inicial en Costa Rica}

\section{RESUMEN}

Contexto: Las reformas educativas en matemática implican una serie de cambios en la formación docente. Algunas de estas modificaciones acentúan la inclusión de nuevos contenidos, el desarrollo de capacidades, habilidades o competencias matemáticas, la implementación de estrategias de enseñanza y evaluativas distintas, y el uso de la tecnología. En Costa Rica, la educación matemática ha experimentado cambios para fomentar en el estudiantado diversos procesos cognitivos, como el proceso de representar. Objetivos: En este artículo se destaca la diversidad de sistemas de representación asignados al concepto de número que propone un grupo de docentes de educación primaria en formación inicial en Costa Rica, como agentes promotores del proceso de representar en el estudiantado. Diseño: La investigación se enmarca en las propuestas sobre el análisis de los significados de conceptos matemáticos y la formación de docentes. Corresponde a un estudio descriptivo basado en un estudio intrínseco de casos. Recolección y análisis de la información: La información se recolectó mediante un cuestionario y su análisis destaca los tipos de representaciones y las justificaciones que este grupo de personas docentes en formación manifiestan para su selección.; se utilizó el análisis de contenido como técnica de análisis. Entorno y participantes: El estudio se llevó a cabo con 23 docentes de educación primaria en formación inicial. Resultados: Los resultados muestran una tendencia al uso de representaciones de un mismo tipo, para mostrar el concepto de número, sobresaliendo las representaciones icónicas y simbóliconuméricas. Conclusiones: Se destaca una vinculación entre las representaciones propuestas y las situaciones y contextos cercanos al estudiantado de educación primaria, en la que valdría la pena profundizar.

Palabras clave: educación primaria; formación inicial de maestros; número; sistemas de representación.

\section{Análise das representações do conceito de número proposto por um grupo de docentes de educação básica em formação inicial na Costa Rica}

\section{RESUMO}

Contexto: As reformas educativas em matemática implicam uma série de mudanças na formação do docente. Algumas destas modificações acentuam a inclusão de novos conteúdos, o desenvolvimento de capacidades, habilidades ou competências matemáticas, a implementação de estratégias de ensino e avaliação distintas e o uso da tecnologia. Na Costa Rica, a educação matemática tem experimentado mudanças para impulsar nos estudantes diversos processos cognitivos, como o processo de representar. Objetivos: Neste artigo destaca-se a diversidade de sistemas de representação atribuídos ao conceito de números que propõe um grupo de docentes de educação básica em formação inicial na Costa Rica, como agentes propulsores do processo de 
representar no corpo discente. Desenho: A pesquisa enquadra-se nas propostas sobre a análise dos significados de conceitos matemáticos e a formação docente. Corresponde a um estudo descritivo baseado em um estudo intrínseco de casos. Coleta e análise de dados: A informação foi coletada mediante um questionário e, em sua análise, destacam-se os tipos de representações e as justificativas que este grupo de docentes em formação manifestam para a sua seleção; foi utilizada a análise de conteúdos como técnica de análise. Cenário e participantes: O estudo foi realizado com 23 docentes de educação básica em formação inicial. Resultados: Os resultados mostram uma tendência ao uso de representações de um mesmo tipo, para mostrar o conceito de número, sobressaindo as representações icônicas e simbólico-numéricas. Conclusões. : Destaca-se uma vinculação entre as representações propostas e as situações e contexto próximos ao discente de educação básica, na qual valeria a pena aprofundar-se.

Palavras-chave: Educação básica; formação inicial de professores; número; sistemas de representação

\section{INTRODUCIÓN}

The study of the meanings of mathematical concepts has managed to pervade the interest of researchers in Didactics of Mathematics. The understanding of a mathematical concept implies that it is endowed with one or more meanings. Different proposals support the process of providing meaning to a mathematical concept from three facets: the sign, the concept, and the meaning (Frege, 1996). These ideas highlight the ways in which the concept is represented, its semantic evaluation, and the different senses in which it can be comprehended, applied or understood (Fernández-Plaza, et al., 2016).

In particular, Rico and Fernández-Cano (2013) highlight the study of meanings through content analysis, a technique to "establish and study the diversity of school meanings of the concepts and procedures of mathematics that appear in a text" (p. 11). Content analysis finds its foundation in Frege's semantic triangle, particularizing the study of the meanings of concepts in school mathematics.

This article focuses on the sign, one of Frege's semantic triangle components, through the study of representation systems. Specifically, the representations of the concept of number proposed by pre-service Primary Education teachers in Costa Rica are analyzed as part of the meaning they give to this mathematical concept.

The concept of number gains prominence in Primary Education, particularly in the early years, where it is essential that children systematically develop this concept, acquire the ability to communicate numerical information, orally and in writing, and develop skills for its recognition, writing 
and reading, and later, for its application in different numerical contexts (Castro, Rico, and Castro, 2007). Moreover, representations constitute a transcendental component in the visualization of a concept in the early school stages (Arcavi, 2003).

Interest for the present study originated during the development of a subject for the Primary Education undergraduate program imparted at the Universidad Estatal de Costa Rica (UNED). During this experience, students-preservice teachers-manifested conceptions "that attracted the attention" regarding the mode of comprehension and understanding of school mathematical concepts, particularly number. The objective of the present study was to exhibit the diversity of representation systems and the justifications for their use provided by the consulted pre-service teachers as regards to the concept of number, in order to analyze from this perspective, the meanings granted to this concept within school mathematics in Costa Rica.

The results of the study reveal a trend towards the use of iconic and symbolic-numeric representations as means to present the concept of number, its connection with contextualized tasks and the use of the concept in diverse situations and contexts, relevant to the Primary Education student.

\section{THEORETICAL FRAMEWORK}

The theoretical foundation of the present study is devised from two focuses. The first pertains to the curricular program established for Primary Education and teacher training in Costa Rica. Within this framework, the conception of number in the Costa Rican Primary Education curriculum is emphasized and the curricular guidelines for the training of teachers are described, accentuating those guidelines associated to mathematical training and the teaching of number. The second point in focus refers to the theoretical foundations on representation systems in the study of meanings of Primary Education mathematical concepts.

\section{Number in the Costa Rican mathematics curriculum}

Public education in Costa Rica is comprised of four educational cycles: Preschool, Primary Education, Secondary Education, and Higher Education (University). Particularly, Primary Education covers cycles I and II (6 years total); Secondary Education includes cycle III (3 years total), with this the Basic General Education [BGE or EGB after its equivalent Spanish acronym] level is 
completed, and cycle IV, called Diversified Education, accounts for the last two years. The study of mathematics is organized around five core mathematical subject areas: numbers, measurements, geometry, relationships and algebra, and statistics and probability (Ministerio de Educación Pública, 2012). Regarding the subject area of numbers, it "occupies a very space in the first two cycles, is relevant in the third and decreases in the diversified [cycle]" (Ministerio de Educación Pública, 2012, p. 50).

From a broader perspective, the curricular program seeks an integrated approach between numbers, operations, and mathematical calculations, underscoring the connection between operations and numeric representations. The latter accentuates the need to study the representations that Primary Education teachers, preservice or in practice, propose to use to present the concept of number to their students. In relation to this topic, a description of the curricular programs for the teaching of number is presented, emphasizing the use of representations for its accomplishment.

Study programs place special attention to the number in cycles I and II at the EGB level of Primary Education. It is proposed to "strengthen the numerical sense" (Ministerio de Educación Pública, 2012, p. 51) through arithmetic operations, the study of numerical properties, mental calculations, and estimations that, at the same time, promote the development of numerical skills. All the above from a functional approach based on problem solving to promote the development of "processes" such as reasoning and argumentation, posing and solving problems, communication, association and representation. In this sense, it is understood that the representation of mathematical concepts or mathematical objects takes prominence when their importance is recognized in the development of the other four mathematical processes.

Regarding number, it is proposed for cycle I the teaching of natural numbers and the operations of addition, subtraction, multiplication, and division; pursuing a connection between the intuitive concept of number and numerical sense.

From the outset, the intuitive concept of number must be connected to numerical sense (the absolute and relative position of numbers), where it becomes relevant to enhance mental calculation and estimation as they activate cognitive processes that advance towards mathematical competence. (Ministerio de Educación Pública, 2012, p. 77) 
The study of number in this first cycle includes, among other intended skills, the identification of examples of diverse representations of a number. These-the numbers-have been introduced to the students by counting and cardinality of sets of objects. Also, it aims to establish correspondences between different forms of representation of natural numbers. For example, in the first year it is proposed to "work on the correspondence between graphic, verbal, and literal representation in expressions such as: $24=20+4(\ldots)$ to provide continuity to the use of various forms of representation" (Ministerio de Educación Pública, 2012, p. 87).

Throughout the second and third years, the representation of numbers is projected via the use of concepts and mathematical relationships addressed through the use of didactic material (manipulatives) and iconic, symbolic and graphical representations; for example, the location of a number on the number line corresponds to the latter representation form.

Cycle II is directed at strengthening mathematical calculations (arithmetic), by exposing students to operations with natural numbers, fractions, and decimals. In the fourth year, for example, the reading and writing of natural numbers and decimals is presented, and the study of fractions through the use of different forms of representation. Also, the use of different representations is encouraged when dealing with operations. Throughout the fifth school year, the use of representations is accentuated in the exposition of fractions and decimal numbers. In the final sixth year of Primary Education, representations are heavily employed when presenting students with the subjects of powers, fractions, and operations dealing with fractions.

In summary, the curricular programs for the teaching and learning of Primary Education mathematics in Costa Rica highlight and bolster the use of diverse representations for the concept of number. As indicated for the first school year, "it is intended to comprehend the meaning of the numbers in order to establish different representations. It is important that the student be able to express a number in different ways (...). Previously, student action must be oriented at verbally expressing equivalences" (Ministerio de Educación Pública, 2012, p. 101).

In this order of ideas, the mathematical knowledge of Primary Education teachers requires a diversity of forms of representation that promote the assignment of meaning, by students, to the concept of number throughout all educational cycles. Representation systems are essential in the teaching of mathematics in Primary Education. 


\section{Pre-service teacher training and mathematics education}

The Primary Education teacher must show a vast understanding of the concepts and procedures that describe and characterize the subjects included in the educational curriculum. Likewise, teachers must possess different pedagogical competences for the performance of their profession.

Hence, pre-service training processes for Primary Education teachers must constitute a source of knowledge, capacities and abilities that promote the formation of a competent professional, in letters and science, prepared from educational practice and keen to permanent training and establishing a classroom teacher-researcher mindset (Llinares, 2008). Its importance is evident in different investigations on initial (preservice) training and knowledge of Primary Education teachers (Alpízar and Arce, 2019; Valverde, 2014).

In the case of mathematics, it is essential that teachers have a solid knowledge of the mathematical and pedagogical content, so that they can intertwine mathematics with different teaching strategies and resources, which promote student learning beyond the teachers' own beliefs and conceptions. Following Arteaga and Macías (2016):

The task of a teacher or professor is too important for the educational action developed in the classroom to be based exclusively on the instructor's personal perception of both the teaching-learning process and the area of knowledge to be taught. (p. 20)

In Costa Rica, pre-service training of Primary Education teachers is carried out by three state universities and eight private universities. AlpízarVargas and Alfaro-Arce (2019) have described Primary Education teacher training plans. Briefly, their study has recognized state universities programs to include subjects on: (a) pedagogy, general didactics, psychology and education; composition of the educational system, administration, educational management, legislation and ethics; evaluation and didactic planning; educational modalities: rural education, single-teacher schools, education for youth and adults; child development, neuroscience, special educational needs, educational innovation, and teaching methodologies; (b) basic subjects such as Spanish, social studies, sciences, including specific didactic courses for imparting these subjects; (c) mathematics, its specific didactics and statistics; (d) teaching practice; (e) educational research; (f) the use of technological tools; 
and $(\mathrm{g})$ other subjects encompassed in the study of other languages, general studies, electives, sports, arts, culture and environment, among others.

In relation to the previous idea, mathematical training includes the study of a diversity of mathematical concepts and procedures, in accordance with curricular guidelines corresponding to this educational level. Following is provided a summary of the mathematical contents included in the mathematics courses provided in Costa Rican state universities.

At the Universidad de Costa Rica (UCR) Primary Education teacher training, up to the baccalaureate level, includes three subjects associated with mathematics and its teaching.

- Mathematics in Primary Education I. The organization of the contents of this course includes the study of natural number and representation systems. Next, it elaborates into the additive and multiplicative structure of natural numbers; rational numbers and the meaning of fractions; and relations and algebra, from the study of ratios, proportionality, equality, constant quantities, and variable quantities. In the course's syllabus, the study of number representations stands out as the first topic to be developed (Universidad de Costa Rica, 2020a).

- Mathematics in Primary Education II. In this course the study of the basic concepts of plane geometry and space are emphasized; followed by the subjects of magnitudes and measurements. Finally, translations, rotations and symmetries are addressed as plane transformations (Universidad de Costa Rica, 2020b).

- Mathematics in Primary Education III. It is oriented to the study of the concepts and basic notions of descriptive statistics, information representation, probability and the materials and resources for its teaching (Universidad de Costa Rica, 2020c).

Complementarily, a seminar course is included dealing with research in Didactics of Mathematics at the school level centered around the organizers of the curriculum and its specificity within Costa Rican Primary Education mathematics (Universidad de Costa Rica, 2020d).

The training of Primary Education teachers at the Universidad Nacional (UNA) at the undergraduate baccalaureate level consists of various general subjects; two of which fall within the scope of Didactic of Mathematics. It 
should be noted that the mathematical content in both subjects is not perceived as a "strong" component (Universidad Nacional, 2015).

- Didactics of Mathematics for Basic Education. This subject includes topics related to mathematics from a didactic perspective; that is, it takes into account teaching, learning, methodological strategies and planning of the mathematics class, among other areas.

- Didactics of Sciences and Mathematics for Basic Education. It includes the study of the subjects included in the curricular program for the teaching of science and mathematics.

The training program at the Universidad Estatal a Distancia (UNED) offers three subjects directly related to mathematics and its didactics, at the baccalaureate level.

- Mathematics I for cycles I and II. It aims to prepare the Primary Education teacher in mathematical and didactic content. As to mathematical content, it points to the study of numbering systems, the set of natural numbers, number theory and the set of positive rational numbers. The introduction to the concept of number is recognized within the scope of the course's objectives: "Describe the characteristics that differentiate the concepts numeric system and numbering system, as well as number and numeral" (Universidad Estatal a Distancia, 2020a, p. 3).

- Mathematics II for cycles I and II. This course addresses the study of proportionality, magnitude and measurement, probability, and the basic elements of statistics. The didactic approach focuses on strategies for the teaching of considered mathematical and statistical concepts (Universidad Estatal a Distancia, 2020b).

- Mathematics III for cycles I and II. This course focuses on the study of geometry, specifying the basic concepts and their relationships, triangles, quadrilaterals, circumference, solids, and geometric transformations (Universidad Estatal a Distancia, 2020c).

By way of summary, it can be indicated that the mathematical training of Primary Education teachers in Costa Rica is characterized from two scopes. 
First, some training programs include the study of basic mathematical concepts associated with arithmetic, measurement, geometry, probability, and statistics. With specificity, these programs, in the subject of arithmetic, address the concept of number, seeking its understanding, the establishment of different modes of use and its diverse representation as a mathematical object. This mathematical approach is accompanied by the study of pedagogical mediation strategies for the teaching of concepts and procedures. Second, study programs pursue to foment teachers' capacities to establish planning, mediation, and evaluation strategies, to incentivize Primary Education students' comprehension and learning of mathematical concepts and procedures, where the approach to mathematical concepts and procedures is a component for the achievement of the main didactic purpose.

\section{Representation of concepts in school mathematics}

In a general framework, representations are conceived as ideas or images that replace reality or some element of it; "one thing that represents another" (Real Academia Española, 2020). Moreover, within the framework of the Didactics of Mathematics, the proposal is different and varied.

In relation to this topic, Castro and Castro (1997) describe representations as "symbolic or graphic notations, specific to each notion, through which mathematical concepts and procedures are expressed, as well as their most relevant characteristics and properties" (p. 96). From this position, representations are not general to the concepts, they are defined and respond to the singularities of each concept.

Moreover, other researchers agree that it is essential to possess or provide a variety of representations for a better understanding and comprehension of mathematical concepts. Following Rico (2013), representations allow greater interaction and access to mathematical knowledge. Vinner and Hershkowitz (1983)-particularly in geometry-emphasize the use of examples in different orientations, when concepts are presented.

From the perspective of Rico, Marín, Lupiáñez and Gómez (2008), a broad knowledge of representation systems, of the relationships between them, between representation systems and the concept, leads to a complete comprehension of the mathematical concept and its meaning. Thus, Barrantes, López and Fernández (2015) sustain that "a scarce variety of representations can lead to an erroneous formation of a concept (...) and, therefore, lead to later 
errors and difficulties." (p. 109). A "restricted" use of representations can lead to the creation of mental schemes far from the reality of the concept (Barrantes and Zapata, 2008). Multiplicity of representations is insufficient to present a concept, it is necessary to take into account the origin of the representation and its incidence on the knowledge of individuals.

Duval (2016), for his part, emphasizes that representations are common tools that enable the communication of specific mental representations that also allow the production of new knowledge. "Representations can be beliefs, individual conceptions or misconceptions, that the individual accesses through verbal or schematic productions." (p. 61)

The curricular programs for school mathematics established by the Ministry of Public Education (MEP by its Spanish acronym) in Costa Rica do not deviate from the above ideas regarding the representations of mathematical concepts. Indeed, this governing body is committed to the use of a diversity of representation systems throughout the teaching of mathematics. Particularly it is insisted that "the cultivation of diverse representations allows a better organization of mathematical ideas to advance in their comprehension and the development of new mathematical forms" (Ministerio de Educación Pública, 2012 , p. 58). The teacher is urged to use unconventional and personal representations in the early years of schooling, and to gradually shift the discourse to more conventional and technical forms as students progress to higher levels.

It is observed that mathematical representations are symbols, expressions, diagrams, or graphs, of dynamic nature, and therefore require a variety of teaching and learning actions. Representations are conceived as a means to unify discourse, communication.

It is very important that, in a stepwise manner, progress be made in the abstraction of mathematical representations to enhance the set of [knowledge in] mathematics that can be learned and used. By progressing into different forms of representation, of increasing [level of] abstraction, more opportunities are offered for the construction of more interesting and complex models for different situations. (Ministerio de Educación Pública, 2012, p. 58)

\section{METHODOLOGY}


The present study is of descriptive nature based on a case study. Following Stake (1999) it corresponds to an intrinsic study of cases, since "Its study [...] does not appeal because we learn about other cases or about some general problem, but because we need to learn about that particular case" ( $p$. 16); that is, the present case under consideration was preselected and its selection deviates from an intentional selection over other cases, as occurs for instrumental case studies.

Methodologically, content analysis is implemented (Rico and Fernández-Cano, 2013), which enables the study of the meanings of a concept from three categories: representation systems, conceptual structure, and contexts and situations. In this case, the study of representation systems stands out, starting from the category of representations. Other investigations, for example, have implemented this technique for the study of concepts and their meanings, from the perspective of the modes of use that pre-service teachers grant to particular mathematical concepts (Chaverri-Hernández, HernandezArce, Castillo-Céspedes, Vallejos-Meléndez and Picado-Alfaro, 2020).

\section{Description of participants}

Participants corresponded to a group of 23 students enrolled in the course "The teaching of mathematics and its processes" of the Primary Education undergraduate program imparted at the Universidad de Costa Rica, during the academic period $2018^{1}$. This subject is assigned to the VII cycle of the study plan, corresponding to the fourth year of the undergraduate program. As indicated in the theoretical framework section, their training already included mathematical instruction, through subjects such as Mathematics in Primary Education I and Mathematics in Primary Education II. Pedagogical training is reinforced by subjects such as Primary Education Sciences I and Primary Education Sciences II. Other subjects taken by participants are associated to different areas of knowledge, such as language, literature, arts, and research.

\section{Information collection}

\footnotetext{
${ }^{1}$ Participants expressed their consent of use and dissemination of all collected information in the present study.
} 
Information was collected through a questionnaire. Each participant was identified by means of a unique questionnaire code; for example, code C$\mathrm{R} 01$ was assigned to participant $\mathrm{N}^{\circ} 1$ 's questionnaire and responses. By way of this instrument, pre-service Primary Education teachers were asked to provide various forms of representations for the concept of number. First, only two forms were requested. Second, participants were instructed to select one of the two previously provided representations which they felt presented more securely the concept of number, and to justify their selection. Finally, they were asked to include other forms of representation, but different from those already provided in item $\mathrm{N}^{\circ} 1$. This instrument was applied in one of the class sessions and was completed individually.

\section{Information analysis}

For analysis of the information, representations were considered as a primary category. The units of analysis were defined based on Duval's (1993) proposal for the study of registered representations. Below is a description of the considered representation forms (Arteaga-Martínez, Macías and Pizarro, 2020; Picado, Gómez and Rico, 2013).

- Verbal. Corresponds to the use of natural language.

- Symbolic-numeric. Predominant use of numbering systems, particularly the decimal numbering system.

- Symbolic-algebraic. Refers to analytical or algebraic expressions.

- Graphic. Includes the Cartesian plane and its components.

- Iconic. Emphasizes the use of images or pictograms, including geometric figures.

- Tabular. Organization of information through rows and columns.

Upon being gathered the participant's responses were analyzed individually. The representations provided in each item of the questionnaire were identified, described, and classified.

\section{ANALYSIS AND RESULTS}


The following treatment provides the results obtained from the analysis of the gathered information; it evidences the representations assigned by a group of teachers to the concept of number at a particular moment in their preservice training. For the purpose of analysis, the first and second representations provided by the participants for item $\mathrm{N}^{\circ} 1$ are defined as representation $\mathrm{A}$ and representation $\mathrm{B}$, respectively.

In this section the information has been organized into three levels of analysis: (a) identification of primary representations; (b) justification expressed by participants relative to the preferential selection of one of the two proposed primary representations; and (c) diversity of the proposed representations. Some data has been tabulated for ease of presentation.

\section{Identification}

The denominated primary representations, hereafter further separated into $\mathrm{A}$ and $\mathrm{B}$, correspond to the first two representations provided by the participants to present the concept of number in response to item $\mathrm{N}^{\circ} 1$ of the applied questionnaire. Representation A and representation B refer to the first and second order of mention by participants, respectively. It can be said that primary representations show the initial attempt-the first occurrence-of preservice teachers to represent number. The quantitative accounting of compiled primary representations in relation to the different forms of representation considered in the present study is summarized in Table 1.

\section{Table 1}

Primary representations $A(1 r s t)$ and $B(2 n d)$ provided by preservice Elementary Education teachers in training at the University of Costa Rica in 2018.

\begin{tabular}{cccccc}
\hline Verbal & $\begin{array}{c}\text { Symbolic- } \\
\text { numeric }\end{array}$ & $\begin{array}{c}\text { Symbolic- } \\
\text { algebraic }\end{array}$ & Iconic & Graphic & Combination \\
\hline \multicolumn{5}{c}{ Representation A } \\
4 & 8 & 1 & 7 & 2 & 1 \\
2 & 8 & 3 & 7 & 0 & 3 \\
\hline
\end{tabular}


As seen in Table 1, the responses to item $\mathrm{N}^{\circ} 1$ amount to 6 verbal representations, 16 symbolic-numeric representations (use of numeral signs), 4 symbolic-algebraic representations (use of letters or signs), 14 iconic representations and 2 graphic representations (based on the use of the number line). The predominance of symbolic-numeric and iconic representations in both the first (A) and second (B) provided representations is clear. Figure 1 exemplifies the use of verbal representations; it presents an explanation of what participant C-R22 conceives as number.

\section{Figure 1}

Example of verbal representation of the concept of number (C-R22's answer to item $\left.N^{\circ} 1,2018\right)^{2}$

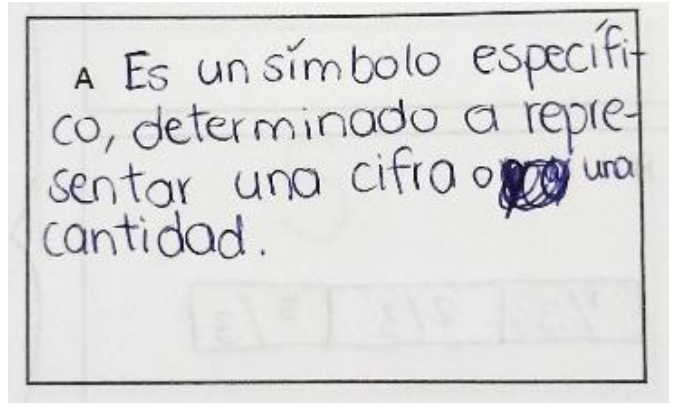

Figure 2 is a graphical representation in which participant C-R09 attempts to depict number as a position on the number line.

\section{Figure 2}

Example of graphic representation of the concept of number (C-R09's answer to item $N^{\circ} 1,2018$ )

2 Translation: It is a specific symbol, determined to represent a figure or a quantity. 


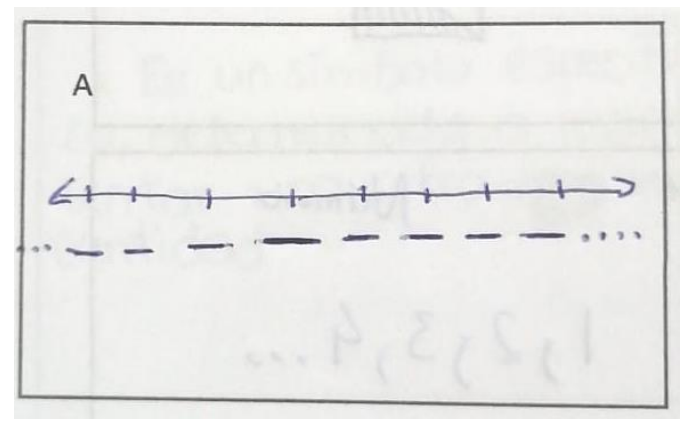

Such primary representations highlight a tendency-or an intention-towards the use of numeric symbology and illustrations or pictograms to present the concept of number.

In addition to the above, the use of combination representations by participants is recognized. For example, two representations are identified that combine the use of pictograms (iconic) and symbolic-numeric forms (Figure 3); one representation combines verbal and symbolic-numeric; and one representation integrates symbolic-numeric and algebraic representations.

\section{Figure 3}

Example of a combined iconic-(symbolic-numeric) representation (C-R22's answer to item $N^{\circ} 1,2018$ )

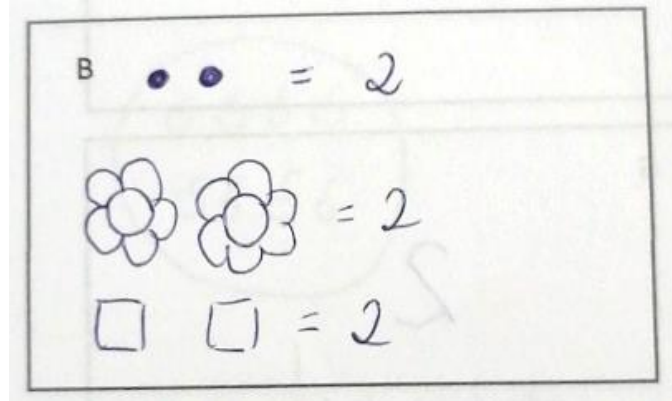

In the responses to item $\mathrm{N}^{\circ} 1$, the use of the notion of set observed in three of the provided iconic representations takes particular emphasis. Unlike the majority of responses, which make independent (uncombined) use of 
illustrations or pictograms, only three participants resorted to set representations-a grouping of objects-, see Figure 4.

\section{Figure 4}

Example of the use of a set representation as part of an iconic representation (C-R23's answer to item $\left.\mathrm{N}^{\circ} 1,2018\right)^{3}$

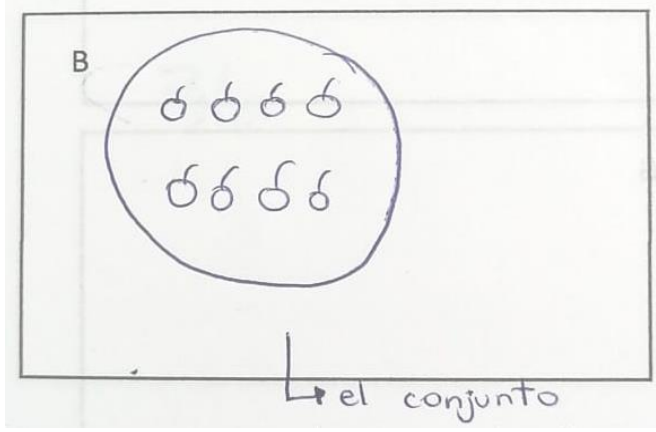

\section{Justification}

From the responses to item $\mathrm{N}^{\circ} 2$ information was collected regarding the preference of participants in selecting one of the two primary representations-obtained from application of item $\mathrm{N}^{\circ} 1$ - and the rationale behind their selection.

Regarding the selection of representation forms, ten participants chose iconic and six favored symbolic-numeric. Those who proposed combination representations would favor this option-the combination of representations-. Further, two participants chose graphic and only one preferred symbolicalgebraic. The expressions that justify any given selection are diverse, although some coincide in terms of a common prevailing idea. Table 2 summarizes the arguments employed as justifications provided by participants or their selection.

\footnotetext{
${ }^{3}$ Translation: The set
} 


\section{Table 2}

Justification criteria for the preferential selection of a given representation by preservice teachers at the University of Costa Rica in 2018

\begin{tabular}{ll}
\multicolumn{1}{c}{$\begin{array}{c}\text { Selected } \\
\text { representation }\end{array}$} & \multicolumn{1}{c}{ Summary of arguments } \\
\hline Iconic & To associate it to a number of objects \\
& To link the abstract with the concrete \\
& To make the concept more visual \\
& To display the cardinality of sets of \\
& objects \\
Fymbolic- & Tor the simplicity of its implementation \\
numeric & To associate a symbol with a quantity \\
& Due to the universal use of numeric \\
& symbols \\
& Due to the student's familiarity with this \\
& type of representation \\
& To contribute to literacy \\
To expose the number sequence
\end{tabular}

Combination

Graphic
To associate a set of elements to a number

To decrease abstraction

To implement ludic activities

To promote understanding of order

relationships

To induce the notion of infinity 
Symbolic-

algebraic
Because of the sense of generality that it creates

Concerning the justifications associated with the selection of iconic representations, the arguments associated with the use of the concrete, visible and tangible, instead of the abstract, stand out, as well as those that are based on the contextualization of the concept of number. Some examples of these expressions are the following: participant C-R14 emphasizes that "in the initial phase it is necessary to relate an abstract concept to something that can be seen, felt and is easily related to previous knowledge so that when comprehension is reached a symbol be established"; participant C-R04 points out that "it is more concrete and it will allow the student to visualize its meaning, I would later use A [a symbolic-numeric representation]". Participant C-R15 argues that "the images are more concrete to acquire the concept of number". Another relevant aspect has to do with the connection established between number and quantity, in this case a variable quantity of objects or elements of a set. In this regard, participant C-R11 highlights that "the number is the expression that indicates cardinality of elements in a set and, therefore, representation with figures, elements or drawings is easier".

The selection of symbolic-numeric representations-shown as some symbol of the Indo-Arabic numeral system-is justified mainly by the common use these types of symbols and their use in different situations familiar to the student. For example, participant C-R07 justifies the selection of symbolicnumeric representation by stating "because it is composed of common and universal numeric symbols within our context"; in turn, participant C-R05 emphasizes "because I consider this to be the form with which students are more familiar" and participant C-R23 points out "I consider this to be the best representation because it will be the one that children use the most throughout their lives".

The use of combination representations is justified from two perspectives: (a) the need to establish a connection between a quantity of concrete objects and a symbolic representation and (b) the need to achieve a level of abstraction about number from the presentation of concrete elements.

Finally, the use of the number line to represent the concept of number acquires support in view of the notion of infinity and of the density that characterizes the set of real numbers-this is interpreted from the justification 
arguments provided by the participants-, as well as the opportunity it presents to introduce students to order relationships. The justification provided by participant C-R09 exemplifies the latter remark: "if it is not comprehended that the number is an element isolated from others, it will be impossible to comprehend what continuity is or the existence of greater and lesser quantities relative to a given number".

\section{Diversity}

Finally, participants indicated other representations that they would use to present the concept of number. The instructions to item $\mathrm{N}^{\circ} 3$ of the questionnaire specified that any additional representations must be different from those already provided in item $\mathrm{N}^{\circ} 1$.

In the results it is observed that one of the participants included four additional representations for the concept of number; 11 participants added three representations; five included two representations; four added one representation and three participants did not include additional representations besides the compulsory two representations provided in item $\mathrm{N}^{\circ} 1$.

From the analysis of the representations, it is possible to affirm that these, for the most part, belong to the same form as primary representations. For example, participant C-R06 who provided one verbal representation and one combination representation (symbolic-numeric and verbal) in item $\mathrm{N}^{\circ} 1$ added three representations upon request by item $\mathrm{N}^{\circ} 3$, the latter combined two forms of representation: iconic and symbolic-numeric. Worthy of mention is the fact that participant C-R07 provided four additional representations, namely: combination, symbolic-algebraic, graphic, and iconic; three of them differ from previously provided primary representations (iconic and symbolic-numeric).

For all participants who provided three additional representations, at least one representation was of the same form as indicated for primary representations. For example, participant C-R15 provided one iconic and one symbolic-numeric primary representation, and additional representations were of symbolic-algebraic, verbal, and symbolic-numeric form.

Of the participants who provided two additional representations, only one (C-R03) included representations of different form relative to previous primary representations. All participants who included only one additional representation did so providing a different representation form. For example, participant C-R12 provided iconic and verbal representations in item $\mathrm{N}^{\circ} 1$, but 
symbolic-numeric as the additional representation. It should be noted that participants C-R02, C-R06 and C-R19 responded item $\mathrm{N}^{\circ} 3$ with three additional representations all of which were of the same form.

\section{CONCLUSIONS}

The present study recognized that, at the moment of presenting the concept of number, the participating Primary Education preservice teachers inclined towards the use of iconic and symbolic-numeric representations. The use of a variety of illustrations referencing food, flowers, animals, geometric objects, school supplies, among others, stand out in iconic representations. Symbolic-numeric representations mostly use numeric symbols taken from the Decimal Numbering System and, to a lesser extent, from Roman, Mayan, and Egyptian numbering systems. Both aforementioned forms of representation are the most frequently employed in combination representations.

As far as the disclosed justification arguments for the preferential selection of one of the two primary representations, the following statements can be established. Some of the arguments are associated to the usefulness of the concept. This coincides with Castro, Rico, and Castro (2007) who affirm that numbers are used in various ways, among which stand out the establishment of a verbal sequence, the action of counting, expressing a quantity of objects or of a measurement, to mark a position or to indicate a code or symbol.

On the other hand, other arguments emphasize the use of certain representations, relating them to teaching strategies that favor the learning of Primary Education students. As indicated by Arteaga-Martínez, Macías and Pizarro (2020), representations "are only a small sample of the resources at one's disposal for the construction and teaching of mathematical knowledge" (p. 269). For example, the iconic representations provided by individuals participating in this study are associated with the use of didactic materials (concrete, tangible) with the purpose of promoting visualization and facilitating the comprehension process of the concept of number.

Also, the results allow to conclude that a group of participants pretend that the use of certain representations-mainly the iconic form-will enable the development of the concept of number in students, for example, through the contextualization of mathematical exercises. In relation to this idea, two aspects are revealed: (1) with the proposed representations it is sought that Primary Education students systematically develop the concept of number, through the 
identification of symbols and numeric terms, and from the establishment of relationships between these and various situations; and (2) this group of preservice teachers acknowledges to be aware of curricular guidelines for the teaching and learning of mathematics in Costa Rica, in which active contextualization is presented as "a special pedagogical component" (Ministerio de Educación Pública, 2012, p. 17) for posing and solving problems in real contexts.

In addition, it is evidenced that the provided representations are part of the theoretical proposals on systems or modes of representation of a mathematical concept (Castro and Castro, 1997; Rico, Marín, Lupiáñez and Gómez, 2008; Maz and Rico, 2009; González-Ruíz and Molina, 2015). Independent representations of verbal, symbolic-numeric, symbolic-algebraic, iconic, and graphic form are identified; other representations combine some of these forms in order to make explicit what is shown: the concept of number. Notoriously, the group of participants omits tabular representations to introduce the concept of number.

Despite the fact that the use of heterogeneous representations is scarce-consider representations of different forms-most participants (17) propose at least three different representations that they would employ to present the concept of number. This could lead to an adequate approach of presenting the concept of number in the teaching process through the use of various representation registers. Nonetheless, the use of these varied representations must be careful and justified, since it constitutes "the threshold of mathematical comprehension for learners at each stage of the curriculum (...) [which] depends on the coordination of several representation registers" (Duval, 2016, p. 91). The results of the present study provide information regarding the treatment that preservice Primary Education teachers give to the concept of number. This contributes to emphasizing the required diversity of representation systems associated with mathematical concepts during training courses.

Finally, some limitations and possible future research within this subject matter are worth to point out. First, despite having obtained an adequate number of representations as responses to the questionnaire, it would have been desirable for the entire group of participants to provide all requested representations; that is, that item $\mathrm{N}^{\circ} 3$ would have provided at least four representations in addition to the two representations already obtained from item $\mathrm{N}^{\circ} 1$. This would have led to a study with a greater diversity of representations. Second, to emphasize the need to deepen the study of the 
relationships that this group of teachers-and teachers in general-establishes between representations and the different phenomena that teachers provide about the concept of number. Furthermore, in a complementary way, one can inquire about the situations and contexts that teachers propose for the study of the concept of number and other mathematical concepts, in adherence to the curricular guidelines issued for the teaching and learning of mathematics in Primary Education in Costa Rica.

\section{ACKNOWLEDGEMENTS}

This study belongs to project PGC2018-095765-B-I00, titled "Competencia profesional del profesor en formación inicial y educación STEM (PROFESTEM)".

\section{AUTHORSHIP CONTRIBUTION DECLARATION}

The idea of the study belongs to M.P.A, author of this article. M.P.A also carried out the adaptation of the study to the theoretical approach herein exhibited; he elaborated and applied the instrument for the collection of information, carried out the analysis of the information and drew up the conclusions of the study.

\section{DECLARATION OF AVAILABILITY OF DATA}

Data supporting the results of this study will be made available by the corresponding author M.P.A upon reasonable request.

\section{REFERENCES}

Alpízar-Vargas, M. \& Alfaro-Arce, A. L. (2019). Percepción de un grupo de docentes de educación primaria acerca de la preparación recibida durante su formación universitaria en cuanto al tema de las Matemáticas [Perception of a Group of Elementary School Teachers About Their College Math Training]. Revista Actualidades Investigativas en Educación, 20(1), 1-31. http://doi.org/10.15517/aie.v20i1.39978. 
Arcavi, A. (2003). The role of visual representations in the learning of mathematics. Educational Studies in Mathematics, 52(3), 215-241. http://doi.org/10.1023/A:1024312321077

Arteaga, B. \& Macías, J. (2016). Didáctica de las matemáticas en educación infantil [Didactc of mathematics in preschool education]. Universidad de La Rioja.

Arteaga-Martínez, B., Macías, J. \& Pizarro, N. (2020). Representation in the solution of mathematical problems: An analysis of metacognitive strategies of secondary education students. Uniciencia, 34(1), 263280. http://doi.org/10.15359/ru.34-1.15

Barrantes, M. \& Zapata M. A. (2008). Obstacles and errors in the teaching and learning of geometrical figures. Campo Abierto, 27(1), 55-71. https://mascvuex.unex.es/revistas/index.php/campoabierto/article/vie $\mathrm{w} / 1985$

Barrantes, M., López, M. \& Fernández, M. A. (2015). Análisis de las representaciones geométricas en los libros de texto [Analysis of geometric representations in textbooks]. PNA, 9(2), 107-127. http://hdl.handle.net/10481/34157

Castro, E. \& Castro, E. (1997). Representaciones y modelización [Representations and modeling]. In Rico, L. (Coordinador) La Educación Matemática en la Enseñanza Secundaria (2nd ed.) (pp. 95124). Horsori.

Castro, E. \& Castro E. (2016). Enseñanza y aprendizaje de las matemáticas en educación infantil [Teaching and learning of mathematics in early childhood education] (Eds.). Pirámide.

Castro, E., Rico, L. \& Castro E. (2007). Números y operaciones.

Fundamentos para una aritmética escolar [Numbers and operations. Bases for school arithmetic] (4 ed.). Síntesis.

Chaverri-Hernández, J., Hernandez-Arce, K., Castillo-Céspedes, M. J., Vallejos-Meléndez, D. \& Picado-Alfaro, M. (2020). What modes of use does the mathematics teacher propose in initial training to teach the Pythagorean theorem in secondary education? Uniciencia, 34(1), 88-110. http://doi.org/10.15359/ru.34-1.6

Duval, R. (1993). Registres de représentation sémiotique et fonctionnement cognitif de la pensée. Annales de Didactique et de Science Cognitives, 
5, 37-65. Translated to Spanish as: Registros de representación semiótica y funcionamiento cognitivo del pensamiento. In F. Hitt, (Ed.), Investigaciones en Matemática Educativa II (pp. 173-201). Iberoamérica.

Duval, R. (2016). Un análisis cognitivo de problemas de comprensión en el aprendizaje de las matemáticas [A cognitive analysis of comprehension problems in learning mathematics]. In R. Duval \& A. Sáenz-Ludlow (Eds.), Comprensión y aprendizaje en matemáticas: perspectivas semióticas seleccionadas (pp. 61-94). Universidad Distrital Francisco José de Caldas.

Etchegaray, S. C. (2017). Análisis de significados personales e institucionales sobre prácticas de divisibilidad en el marco del enfoque ontosemiótico [Analysis of personal and institutional meanings on divisibility practices within the framework of the ontosemiotic approach]. In J. M. Contreras, P. Arteaga, G. R. Cañadas, M. M. Gea, B. Giacomone, \& M. M. López-Martín (Eds.), Actas del Segundo Congreso International Virtual sobre el Enfoque Ontosemiótico del Conocimiento y la Instrucción Matemáticos. http://enfoqueontosemiotico.ugr.es/civeos.html

Fernández-Plaza, J. A., Castro-Rodríguez, E., Estrella, M., Martín-Fernández, E., Rico, L., Ruiz-Hidalgo, J. F. \& Vílchez-Marín, M. (2016).

Significado y concepciones de conceptos matemáticos escolares [Meaning and conceptions of school mathematical concepts]. In J. A. Macías, A. Jiménez, J. L. González, M. T. Sánchez, P. Hernández, C. Fernández, F. J. Ruiz, T. Fernández, \& A. Berciano (Eds.), Investigación en Educación Matemática XX (pp. 237-246). [In Spanish]. SEIEM.

Frege, G. (1996). Estudios sobre semántica. Escritos filosóficos [Studies on semantics. Philosophical writings] (pp. 147-264). Crítica-Grijalbo Mondadori.

González-Ruiz, I. \& Molina, M. (2015). Representaciones y fenómenos que organizan la relación de equivalencia. Un estudio experimental con maestros en formación inicial en el contexto de la geometría básica [Representations and phenomena that organize the equivalence relation. An experimental study with pre-service teachers in the context of basic geometry]. In C. Fernández, M. Molina, \& N. Planas 
(eds.), Investigación en Educación Matemática XIX (pp. 309-316). SEIEM.

Llinares, S. (2008). Constructing the necessary knowledge for teaching math: Social practice and technology. Revista de Educación a Investigación, 3(1), 7-30. http://hdl.handle.net/10045/10435

Maz, A. \& Rico, L. (2009). Negative numbers in the 18th and 19th centuries: phenomenology and representations. Electronic Journal of Research in Educational Psychology, 17, 537-554. http://ojs.ual.es/ojs/index.php/EJREP/article/view/1343/1483

Ministerio de Educación Pública (2012). Programa de Estudio. Matemáticas [Study programme. Mathematics]. Autor.

Picado, M., Gómez, B. \& Rico, L. (2013). El análisis didáctico en el estudio del Sistema Métrico Decimal en un libro de texto histórico de matemáticas [Didactic analysis in the study of Metric System in a historical textbook of mathematics]. In L. Rico, J. L. Lupiáñez \& M. Molina (Eds.), Análisis didáctico en Educación Matemática. Metodología de investigación, formación de profesores e innovación curricular (pp. 403-414). Comares.

Real Academia Española (2020). Diccionario de la Lengua Española (23th ed.). https://dle.rae.es/representaci\% $\mathrm{C} 3 \% \mathrm{~B} 3 \mathrm{n}$ ?m=form.

Rico, L. (2013). Antecedentes del análisis didáctico en Educación Matemática [Background of didactic analysis in mathematics education]. In L. Rico, J. L. Lupiáñez \& M. Molina (Eds.), Análisis didáctico en Educación Matemática. Metodología de investigación, formación de profesores e innovación curricular (pp. 23-58). Comares.

Rico, L. \& Fernández-Cano, A. (2013). Análisis didáctico y metodología de investigación [Didactic analysis and research methodology]. In L. Rico, J. L. Lupiáñez \& M. Molina (Eds.), Análisis didáctico en Educación Matemática. Metodología de investigación, formación de profesores e innovación curricular (pp. 1-22). Comares.

Rico, L., Marín, A., Lupiañez, J. L. \& Gómez, P. (2008). Planificación de las matemáticas escolares en secundaria. El caso de los números naturales [Planning of school mathematics in secondary school. The case of natural numbers]. Suma, 58, 7-23. 
Stake, R. E. (1999). Investigación con estudios de caso [Research with case studies] ( $2^{\mathrm{a}}$ ed.). Morata.

Universidad de Costa Rica (2020a). Matemática en la Educación Primaria I (FD0401) [Mathematics in Primary Education I]. Escuela de Formación Docente. Sección de Educación Primaria.

Universidad de Costa Rica (2020b). Matemática en la Educación Primaria II (FD0515) [Mathematics in Primary Education II]. Escuela de Formación Docente. Sección de Educación Primaria.

Universidad de Costa Rica (2020c). Matemática en la Educación Primaria III (FD0259) [Mathematics in Primary Education III]. Escuela de Formación Docente. Sección de Educación Primaria.

Universidad de Costa Rica (2020d). Seminario Investigación en Didáctica de la Matemática en la etapa escolar (FD0264) [Seminar. Research in didactic of mathematics in school level]. Escuela de Formación Docente. Sección de Educación Primaria.

Universidad Estatal a Distancia (2020a). Orientaciones académicas matemática I para I y II ciclos (Código 00809) [Mathematical academic orientations I for cycles I and II]. Author. http://orientacionesacademicas.uned.ac.cr/consultas/.

Universidad Estatal a Distancia (2020b). Orientaciones académicas matemática II para I y II ciclos (Código 00810) [Mathematical academic orientations II for cycles I and II]. Author. http://orientacionesacademicas.uned.ac.cr/consultas/.

Universidad Estatal a Distancia (2020c). Orientación académica matemática III para I y II ciclos (Código 02102) [Mathematical academic orientations III for cycles I and II]. Author. http://orientacionesacademicas.uned.ac.cr/consultas/.

Universidad Nacional (2015). Actualización del plan de estudios de la Licenciatura en Pedagogía con énfasis en I y II ciclos de la Educación General Básica, en el marco de la flexibilización curricular 2013-2015. CIDE. https://www.cidebasica.una.ac.cr/index.php/documentos/category/1-plan-de-estudios.

Valverde, G. (2014). Experimentos de enseñanza: una alternativa metodológica para investigar en el contexto de la formación inicial de docentes [Teaching experiments: a methodological alternative to 
research in the context of the initial teacher training]. Revista Actualidades Investigativas en Educación, 14(3), 1-20.

http://doi.org/10.15517/AIE.V14I3.16095

Vinner, S. \& Hershkowitz, R. (1983). On concept formation in geometry.

ZentralblattfürDidaktik der Matematik, 83(1), 20-25.

https://www.researchgate.net/publication/284382026 On concept for mation_in_geometry 
